\title{
En mann i 40-årene med vekttap og hevelse i scrotum
}

\author{
Hevelser i scrotum kan være tegn på en rekke alvorlige sykdommer. \\ Videre utredning er derfor viktig. Denne kasuistikken illustrerer \\ aktuelle differensialdiagnoser og beskriver sjeldne komplikasjoner \\ til en vanlig sykdom.
}

Se kommentar side 2028 og kunnskapsprøve på www.tidsskriftet.no/quiz

\author{
Kjersti Nøkleby \\ Lungemedisinsk avdeling \\ Viktor Berge \\ Oslo urologiske universitetsklinikk \\ Morten Stiris \\ Radiologisk avdeling

\section{Kjersti Forberg Tufteland} \\ Patologisk anatomisk laboratorium \\ Sjur Humerfelt \\ sjur.humerfelt@aus.no \\ Lungemedisinsk avdeling \\ Oslo universitetssykehus, Aker \\ Trondheimsveien 235 \\ 0514 Oslo
}

En tidligere frisk mann i 40-årene ble innlagt i sykehus med spørsmål om cancer testis. Han hadde kommet til Norge som asylsøker noen måneder før. Flere ganger hadde han oppsøkt legevakten pga. slapphet, nedsatt matlyst og et sår på høyre legg. Innleggelsesdagen klaget han i tillegg over smerter i begge lysker og en forandring i scrotum, uten at det hadde vært noe forutgående traume. Han hadde følt seg syk i en måned, med et vekttap på $10 \mathrm{~kg}$, og hadde kjent en hevelse i scrotum siste uke. Ved palpasjon ble det i høyre del av scrotum påvist en uøm oppfylling som ikke var gjennomlysbar.

Testikkelkreft er vanligste kreftform hos unge menn, og den oppdages som oftest som en fast eller hard kul i en testikkel. Manglende gjennomlysbarhet gjorde hydrocele og spermatocele lite aktuelt. Andre differensialdiagnoser ved tumor i scrotum inkluderer epididymitt, orkitt, lyskebrokk, blødning, testistorsjon og varikocele.

Ved ankomst $i$ sykehuset hadde han ingen urinveissymptomer, og han var $i$ god allmenntilstand og afebril. Det var normale funn ved hjertet, lunger og abdomen og ingen palpable lymfeknuter i lyskene eller på halsen. I scrotum palperte man en opp- fylling kranialt og festet til høyre testis. I tillegg var det et ekkymoseliknende sår, $5 \times 7$ $\mathrm{cm}$, på høyre legg. Blodprøver viste $S R$ $24 \mathrm{~mm}, \mathrm{CRP} 27 \mathrm{mg} / \mathrm{l}, \mathrm{Hb} 12,5 \mathrm{~g} / 100 \mathrm{ml}$, hvite blodceller 7,6 $10 \% / \mathrm{l}$, Na $125 \mathrm{mmol} / \mathrm{log} \mathrm{Cl} 92$ mmol/l. Øvrige blodprøver var normale.

Slapphet, nedsatt matlyst, vekttap og lett økte inflammasjonsmarkører kan tyde på kreft eller kronisk infeksjon. Hos en innvandrer fra et utviklingsland vil derfor tuberkulose være noe av det første man bør tenke på.

Ultralyd scrotum viste på høyre side en ekstratestikulær hypoekkogen oppfylling på $15 \times 30 \mathrm{~mm}$ i nær relasjon til selve epididymis. Høyre testis var hyperemisk og noe forstørret, men ikke tumorsuspekt. Det var normale forhold på venstre side. Disse funnene ga mistanke om tuberkuløs epididymitt.

Alle mistenkelige oppfyllinger i scrotum bør utredes med ultralydundersøkelse. Denne gir detaljert anatomisk informasjon med høy sensitivitet og spesifisitet ved for eksempel testistorsjon, infeksjon, varikocele, traume og tumor (1). Tuberkulose i scrotum er vanligvis tuberkuløs epididymitt. Vanligste symptomer er skrotal hevelse og ømhet, men hematuri, «steril pyuri» og hydroceledanning forekommer også (2).

Pasienten benektet tidligere kjent tuberkulose hos ham selv eller i familien. Han hadde ikke hatt dyspné, hoste eller hemoptyse. Det var blitt målt feber ved kun én av konsultasjonene ved legevakten, og han hadde ingen nattesvette. Han var BCG-vaksinert i hjemlandet, og skjermbildet av lungene ved ankomst Norge hadde vært negativt. Det ble tatt røntgen thorax og Mantoux' test samt direktemikroskopi og dyrking av ekspektorat, urin, sårsekret og avføring med tanke på tuberkelbasiller. Tester for hiv, syfilis og parotittvirus var negative.

Tuberkulose må bekreftes med mikrobiologiske undersøkelser. Påvisning av syrefaste staver ved direkte mikroskopi er imidlertid lite sensitivt, og dyrking tar opptil åtte uker.

Røntgen thorax viste disseminert utbredelse av smånodulære, stedvis dels konfluerende små fortetninger $i$ begge lunger (fig 1). Grunnet mistanke om smitteførende tuberkulose ble pasienten isolert. Bronkoskopi ble utført.

Differensialdiagnoser til miliære fortetninger fra tuberkulose inkluderer lungemetastaser, sarkoidose, hypersensitivitetspneumoni og pneumokoniose (3). Ved lungemetastaser er miliære fortetninger ved røntgen thorax et uvanlig mønster, og er da som oftest assosiert med høyvaskulære tumorer som nyrecancer, melanom eller thyreoideakarsinom.

Finnålsaspirasjon fra scrotum var mislykket. Han ble derfor operert med tanke på biopsi. Høyre epididymis var ruborøs, oppsvulmet og adherent til testis, med palpatoriske forandringer i nærmest hele øvre halvdel av testis. Både epididymis og testis på høyre side ble fjernet. I operasjonsmateria-

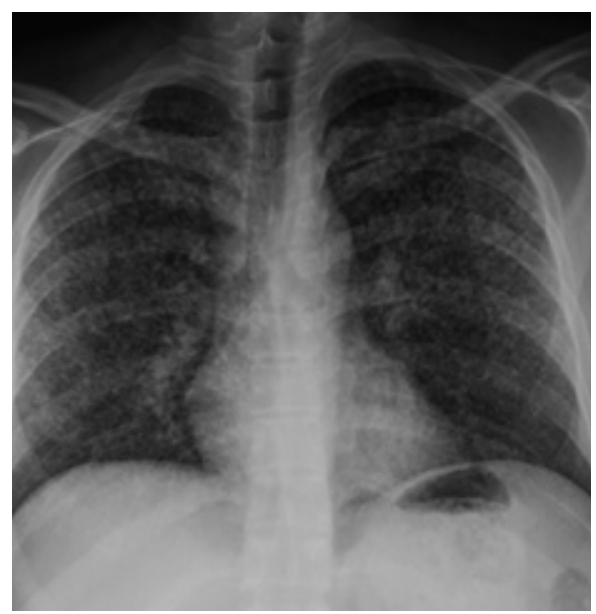

Figur 1 Røntgen thorax ved innkomst i sykehuset viser disseminert utbredelse av smånodulære, stedvis dels konfluerende små fortetninger $i$ begge lunger 
let ble det påvist utbredt granulomatøs betennelse med nekroser og enkelte syrefaste staver (fig 2). Mantoux' test var positiv, med et infiltrat på $15 \mathrm{~mm}$. Behandling med perorale tuberkulostatika ble startet etter vanlige retningslinjer (4).

Pasienten hadde altså miliær tuberkulose med tuberkuløs epididymoorkitt. Miliær tuberkulose opptrer vanligvis i tilknytning til primærinfeksjonen eller noen måneder etter denne, men kan også manifestere seg flere år etter.

Første svar på dyrking av ekspektorat forelå etter 13 dager og viste vekst av syrefaste staver. Senere ble det påvist oppvekst også i urin, bronkialskyllevæske og i operasjonsmaterialet fra scrotum. Hybridisering viste at bakteriene tilhørte Mycobacterium tuberkulosis-komplekset. Endelig resistensbestemmelse forelå to uker etter første svar på dyrkingen og viste sensitivitet for alle de aktuelle medikamentene. CT abdomen var negativ.

Pasienten hadde siden innleggelsen vært $ø$ øende kvalm med oppkast. Etter oppstart av tuberkulostatikabehandling hadde han i tillegg konstant moderat hodepine.

Man mistenkte derfor cerebral affeksjon.

Pasienten var ikke nakkestiv, han hadde god muskelkraft, men med nedsatt tempo. Det var normal sensibilitet, ingen synsforstyrrelser, normal oftalmoskopi. MR caput ble mislykket grunnet ubehag, CT caput var normal. Ved spinalpunksjon ble det påvist klar spinalvæske, men med betydelig forhøyet proteinnivå $(1,8 \mathrm{~g} / \mathrm{l}$ mot normalt $<0,4 \mathrm{~g} / \mathrm{l})$. Det var også en patologisk ratio mellom glukose $i$ spinalvæske og serum 10,3 mot normalt $>0,5$ ). Celletallet var også økt (hhv. $13 / \mathrm{mm}^{3}$ og $17 / \mathrm{mm}^{3}$, mot normalt $<4 / \mathrm{mm}^{3}$ ).

MR er bedre enn CT ved alle cerebrale tuberkuloseformer, negativ $\mathrm{CT}$ utelukker ikke cerebral affeksjon. Pasienten hadde biokjemiske funn i spinalvæsken typisk for tuberkuløs meningitt. Både steroider og aminoglykosidet amicacin ble vurdert, men det ble ikke funnet indikasjon for dette.

Pasienten hadde også under det meste av oppholdet hyponatremi.

Uhensiktsmessig høy sekresjon av antidiuretisk hormon (ADH) - SIADH - kan forekomme ved tuberkulose, og spesielt hyppig ved miliær eller meningeal tuberkulose.

Pasienten var fortsatt kvalm og kastet opp, men konsentrasjonen av rifampicin i serum tydet på godt tarmopptak og tilstrekkelig dosering. Etter tre uker med medikamentell behandling var det symptomforverring. Det ble da startet opp med intramuskulære injeksjoner med amicacin (Biklin) som tilleggsmedikament til de perorale medikamentene. Etter dette var det rask bedring.

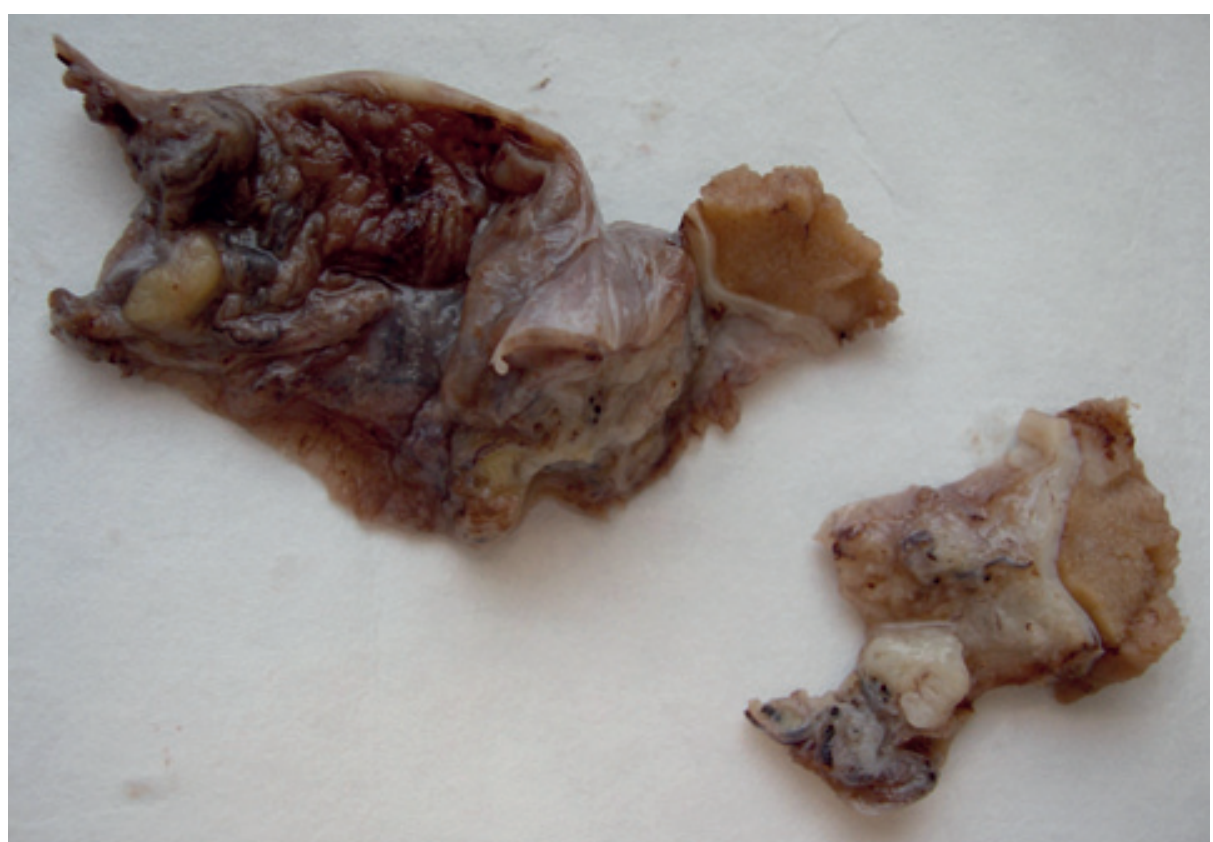

Figur 2 Operasjonsmaterialet fra epididymis og testis viser utbredt granulomatøs betennelse med nekroser og enkelte syrefaste staver ved mikroskopi

MR caput ble deretter utført og viste utallige tuberkulomer $i$ både lillehjernen, storhjernen og hjernestammen, med ødemer omkring (fig 3). I tillegg fant man fortykkede meninger over høyre hemisfære av storhjernen. På ny ble steroidbehandling vurdert, uten at dette ble gitt.

Etter seks uker ble han utskrevet fra sykehuset med daglig direkte observert terapi (DOT-regime) videre ved hjelp av hjemmetjenesten. Han hadde noe nedsatt koordinasjon og gikk tregt i trapper. Dette normaliserte seg gradvis, likeså forandringene på røntgen thorax.
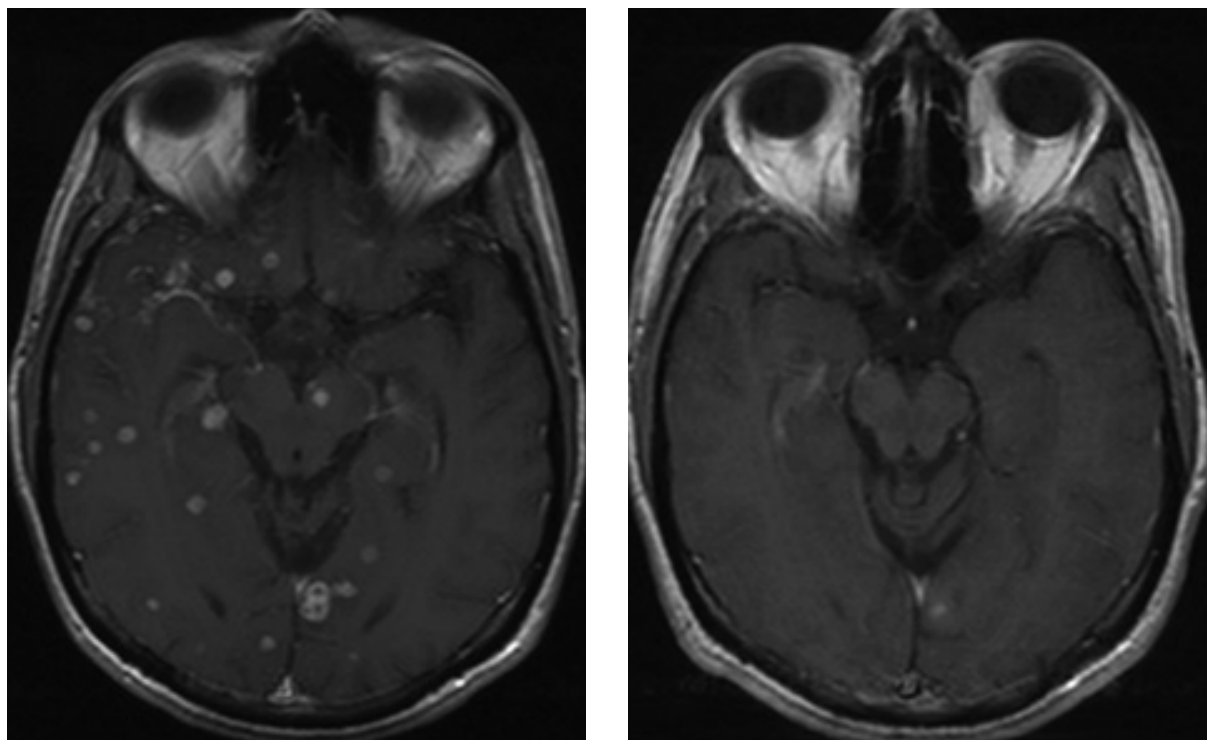

Figur 3 MR caput med aksiale T1-snitt etter omniskan intravenøst tatt fire uker etter innleggelsen viser kontrastopptak i cerebrale tuberkulomer med lett omkringliggende ødemer
Ved polikliniske kontroller første halvår var pasienten bedre både motorisk og når det gjaldt den generelle allmenntilstanden. Vekten hadde økt med ca. $5 \mathrm{~kg}$. Hovedproblemet var smerter i gjenværende venstre scrotum. Ni måneder etter første innleggelse ble venstre epididymis eksidert på grunn av abscessdanning. Ved direkte mikroskopi av denne vevsprøven var Ziehl-Nielsen-fargingen positiv, men dyrkingen negativ.

Til sammen fikk pasienten antituberkuløs behandling i 12 måneder. Ved siste kontroll tre år etter innleggelsen var han i god allmenntilstand og i fullt arbeid. MR caput tatt

Figur 4 Kontroll MR caput med aksiale T1-snit etter omniskan intravenøst tatt ti måneder etter avsluttet tuberkulostatikabehandling viser betydelig tilbakegang av tuberkulomene. Det ses kun et lite restområde medialt i høyre oksipitallapp 
ca. ett år etter avsluttet behandling viste betydelig tilbakegang av tuberkulomene (fig 4).

\section{Diskusjon}

Pasienten hadde disseminert spredning av $M$ tuberkulosis til en rekke av kroppens indre organer (lungene, urinveiene og sentralnervesystemet). Denne kombinasjonen er meget sjelden i Norge i dag. Årlig meldes urinveisaffeksjon hos $1 \%$, miliær spredning hos $1 \%$ og sentralnerveaffeksjon hos $0,5 \%$ av alle nye tilfeller med tuberkulose (5).

De aller fleste tuberkulosepasienter i Norge i dag er utenlandskfødte. Man antar at de fleste av disse er smittet $i$ opprinnelseslandet eller under reisen til Norge (6). Mange asylsøkere har trange og dårlige boforhold også etter ankomst til landet. Vår pasient bodde sammen med en rekke av sine landsmenn under meget vanskelige forhold. Siden han tidligere var BCG-vaksinert, var uten kjent tuberkulose og hadde negativt skjermbilde av lungene ved ankomst til Norge, er det mulig at han er blitt smittet her i landet. Denne mistanken ble styrket av informasjon om at en i bofellesskapet hadde startet behandling mot mistenkt lungetuberkulose før vår pasient ble syk.

Epididymitt er den vanligste manifestasjonen av urogenital tuberkulose (7). Den mest sannsynlige patogenesen er hematogen spredning til en nyre fra et primærfokus i en lunge. Etter reaktivering kan tuberkelbasiller spres via urinveiene til prostata og sædblærer, deretter retrograd til epididymis. Andre smitteveier til epididymis kan være direkte hematogen spredning dit, seksuell smitte eller smitte ved intravesikal BCGterapi ved overflatisk blærekreft. De fleste med urogenital tuberkulose har også nyreaffeksjon. Vår pasient hadde verken symptomer eller tegn til dette, men urindyr- kingen var positiv. Dette tyder på at han mest sannsynlig hadde et lite fokus også i nyrene.

Miliær tuberkulose har ubehandlet dårlig prognose. Det er vanligst hos immunsvekkede (3). Hos vår pasient fant vi ingen bakenforliggende årsak.

Cerebral affeksjon av tuberkulose er også en meget alvorlig tilstand. Avhengig av nevrologiske funn klassifiseres denne til stadium 1 (ingen utfall), stadium 2 (utfall uten bevissthetstap) eller stadium 3 (koma) (8). Steroider er nå anbefalt ved alle disse stadiene for å forhindre eller begrense alvorlige komplikasjoner. Men på behandlingstidspunktet var det mer vage retningslinjer, og vi konsulterte fire infeksjonsmedisinere, som alle mente steroider ikke var indisert. Uansett stadium vil man også forlenge den ordinære medikamentelle behandlingen. Uten behandling dør pasienter med tuberkuløs meningitt vanligvis innen seks uker, med adekvat behandling synker mortaliteten til ca. $25 \%$ (9). Blant de overlevende vil omtrent halvparten ha ulike grader av varige nevrologiske skader. Vår pasient overlevde uten noen form for nevrologisk sekvele.

Etter oppstart av tuberkulostatikabehandling får en betydelig andel av pasientene en såkalt paradoks reaksjon - den eksisterende sykdommen forverres eller det kommer nye lesjoner på tross av adekvat behandling (10). En slik reaksjon er uforutsigbar både både når det gjelder debut, varighet og alvorlighetsgrad og er sannsynligvis immunologisk betinget. Vår pasient utviklet sannsynligvis dette, i og med at han fikk økende hodepine og epididymitt på motsatt side under pågående adekvat behandling. Ved en forverring av tilstanden må en slik reaksjon ikke forveksles med behandlingssvikt eller andre komplikasjoner til sykdommen.
Denne sykehistorien viser at helsepersonell må ha lav terskel for å mistenke tuberkulose hos utenlandskfødte som oppsøker legevakt eller akuttmottak av ulike grunner. Trange og dårlige boforhold for asylsøkere representerer en betydelig smitterisiko ved lungetuberkulose.

Pasienten har gitt samtykke til at artikkelen blir publisert.

Oppgitte interessekonflikter: Ingen

Litteratur

1. Doherty FJ. Ultrasound of the nonacute scrotum. Semin Ultrasound CT MR 1991; 12: 131-56.

2. Cek M, Lenk S, Naber KG et al. EAU guidelines for the management of genitourinary tuberculosis. Eur Urol 2005; 48: 353-62

3. Andreu J, Mauleón S, Pallisa E et al. Miliary lung disease revisited. Curr Probl Diagn Radiol 2002: 31: 189-97.

4. Gulsvik A. Tuberkulose. I: Foreningen for utgivelse av Norsk legemiddelhåndbok. Norsk legemiddelhåndbok for helsepersonell 2007. Oslo: Fagbokforlaget, 2007: 344-6.

5. Winje B, Mannsåker T, Heldal E et al. Tuberkulose i Norge i 2005. MSIS-rapport 2006; nr. 34: 33.

6. Dahle UR, Sandven P. Heldal E et al. Continued Low rates of transmission of Mycobacterium tuberculosis in Norway. J Clin Microbiol 2003; 41: 2968-73.

7. Türkvatan A, Kelahmet E, Yazgan C et al. Sonographic findings in tuberculous epididymo-orchitis. J Clin Ultrasound 2004: 32: 302-5.

8. Katti MK. Pathogenesis, diagnosis, treatment, and outcome aspects of cerebral tuberculosis. Med Sci Monit 2004; 10: RA215-29

9. Schlossberg D. Tuberculosis and nontuberculous mycobacterial infections. 5. utg. New York, NY: McGraw-Hill, 2006.

10. Breen RA, Smith CJ, Bettinson $\mathrm{H}$ et al. Paradoxical reactions during tuberculosis treatment in patients with and without HIV co-infection. Thorax 2004; 59: 704-7.

Manuskriptet ble mottatt 11.5. 2009 og godkjent 3.6. 2010. Medisinsk redaktør Anne Kveim Lie.

\section{Noen sykdommer kommer tilbake}

Effektive medisiner og omfattende forebyggende tiltak ga i 1960-70-årene håp om at tuberkulosen var under kontroll. Både globalt og i Norge sank forekomsten, og insidensen her i landet var blant de laveste i verden. Flere faktorer førte imidlertid til økende forekomst fra midten av 1980-årene. I flere land har kontrollprogrammene brutt sammen på grunn av krig, overbelastet helsevesen og mangelfull forståelse for nødvendigheten av ulike tiltak $(1,2)$. Økningen i insidens globalt skyldes $\mathrm{i}$ hovedsak økt reaktivering og smittespredning på grunn av hivepidemien. Her i landet er det i stor grad flere tuberkulo- setilfeller blant innvandrere som ligger bak. I tillegg har vi fătt økende utvikling av resistens, i hovedsak på grunn av mangelfull medikamentetterlevelse og kontroll.

Et av de viktigste milleniumsmålene for WHO var reduksjon i forekomst av og mortalitet ved tuberkulose (3). Det viktigste tiltaket - DOTS-strategien (direkte observert terapi) - har lenge vært anbefalt også her i landet og har vært søkt gjennomført ved hjelp av tuberkulosekoordinatorer. Det har vært reist tvil om nytten av DOTS-opplegget, som kan føre til stigmatisering og ofte er problematisk for mange pasienter. Det er imidlertid meget viktig at pasientene følges nøye opp, for også ved Oslo universitetssykehus, Ullevål, har vi sett utvikling av multiresistent tuberkulose (MDRTB) og sekundær spredning til en rekke pasienter som følge av mangelfull oppfølging, hovedsakelig $i$ et innvandrermiljø (upubliserte data). En vesentlig del av tilfellene av multiresistent tuberkulose i Norge skyldes mangelfull oppfølging og behandling.

Mens vekttap, nattesvette, høy senkningsreaksjon og anemi ofte skyldes malign sykdom, bør man hos innvandrere først og fremst tenke på tuberkulose. Sykdomsbildet 